\title{
PARASITOLOGY
}

(Founded by G.H.F.Nuttall)

\author{
EDITED BX \\ D. KEILIN
}

IN CONJUNCTION WITH

H. A. BAYLIS

A. BISHOP

F. J. BROW N

P. A. BUXTON

C. DOBELL
E. HINDLE

C. A. HOARE

G. LAPAGE

K. M. SMITH

N. G. SPROSTON

P. TATE

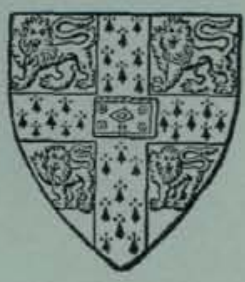

CAMBRIDGE UNIVERSITY PRESS CAMBRIDGE, AND BENTLEY HOUSE, LONDON AGENTS FOR U.S.A. THE UNIVERSITY OF CHICAGO PRESS CANADA AND INDIA: MACMILLAN

Thirty-seven Shillings net 
BACTERIOLOGIST

required by

\section{British LAUNDERERS' \\ Research Association}

Commencing salary $£ 55^{\circ}$ rising to $£ 75^{\circ}$ p.a. by increments of $£^{25}$. F.S.S.U. benefits.

Apply with full particulars of training and experience to Director, B.L.R.A. Laboratories, Hill View Gardens, Hendon, N.W. 4 .

\section{Stains \& Reagents FOR MICROSCOPY}

Azocarmine B \& G

Brilliant Cresyl Blue

Cedarwood Oil

Fast Green FCF

Giemsa Stain

Indicators

Janus Blue

Janus Green
Azur I \& II

Evans Blue

\author{
Janus Red \\ Jenner Stain \\ Leishman Stain \\ May-Grunwald Stain \\ Nile Blue Sulphate \\ Pontamine Sky Blue \\ Rosolic Acid \\ Sudan I, II, III \& IV \\ Sudan Blue \\ Wax for embedding
}

Water Soluble Indicators

Stains in tablet form Etc. Etc.

Microscope Slides, Coverslips, Laboratory Sundries

Price Lists on application

EDWARD GURR LTD.

108 WATERFORD ROAD

WALHAM GREEN, LONDON, S.W. 6

Tel.: Renown 2011 Cables: Gurr, Renown zorr, London

For Uniform High QUality, Reliability

AND ImMediate Delivery, STIPUlate

\section{The}

\section{TREMATODA}

\section{BEN DAWES}

A detailed study of the trematode parasites of vertebrate animals such as the advanced student of zoology dissects in the laboratory, intended to give zoologists and parasitologists a more useful account of the Trematoda than can be found in existing works. The author is Lecturer in Zoology at King's College, London.

$$
\text { s2s. 6d. net }
$$

\section{- CAMPBRIDGE UNIVERSITY PRESS}




\title{
PARAS I TOLOGY
}

(Founded by G. H. F. Nuttall, F.R.S.)

\author{
EDITED BY \\ D. KEILIN
}

IN CONJUNCTION WITH
H. A. BAYLIS
E. HINDLE
A. BISHOP
C. A. HOARE
F. J. BROWN
G. LAPAGE
P.A. BUXTON
K. M. SMITH
C. DOBELL
N. G. SPROSTON
P. TATE

VOLUME $39,1948-49$

CAMBRIDGE

AT THE UNIVERSITY PRESS

1949 
Printed in Great Britain at the University Press, Cambridge (Brooke Crutchley, University Printer) and published by the Cambridge University Press Cambridge, and Bentley House, London

Agents for U.S.A.: The University of Chicago Press Canada and India: Macmillan

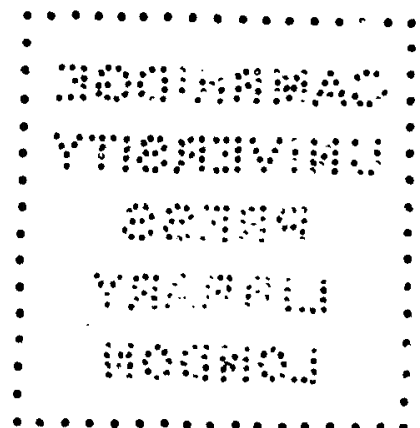




\section{O N T E N T S}

\section{Nos. 1, 2 (JणLY 1948)}

Busvine, J. R. The 'head' and 'body' races of Pediculus humanus L. (With Plate I and 7 Figures in the Text)

Crofton, H. D. The ecology of immature phases of Trichostrongyle nematodes. I. The vertical distribution of infective larvae of Trichostrongylus retortaeformis in relation to their habitat. (With 5 Figures in the Text)

Crofton, H. D. The ecology of immature phases of Trichostrongyle nematodes. II. The effect of climatic factors on the availability of the infective larvae of Trichostrongylus retortaeformis to the host. (With 6 Figures in the Text) .

LAWREnce, R. F. Some new pilicolous mites from South African mammals. (With 8 Figures in the Text)

Satchell, G. H. The respiratory horns of Psychoda pupae (Diptera: Psychodidae). (With 27 Figures in the Text).

ArthUR, D. R. On the egg of the tick, Ixodes ricinus L. (With 12 Figures in the Text) .

MACLeOD, JoHs. The distribution and dynamies of ked populations, Melophagus ovinus Linn. (With 4 Figures in the Text).

Hansen, Eder L. and Anderson, Hameton H. An essentially syntheúc liquid medium for Entamoeba histolytica

Sproston, Nora G. On the genus Dinobothrium van Beneden (Cestoda), with a description of two new species from sharks, and a note on Monorygma sp. from the electric ray. (With 25 Figures in the Text).

Meyer, H. and Xavier de Oliveira, M. Cultivation of Trypanosoma cruzi in tissue cultures: a four-year study. (With Plates II and III) . . . . . . . . . . .

Adler, S. and Feldman-Muensam, B. A note on the genus Hyalomma Koch in Palestine. (With 8 Figures in the Text).

TATE, P. The technique for breeding pure-line cultures of the blow-fly (Calliphora erythrocephala). (With 3 Figures in the Text) .

ROGERS, W. P. The respiratory metabolism of parasitic nematodes. (With 2 Figures in the Text)

Tripathi, Yogendra R. Some new Myxosporidia from Plymouth with a proposed new classification of the Order. (With 6 Figures in the Text)

Buxton, P. A. Experiments with mice and fleas. I. The baby mouse. (With 2 Figures in the Text)

Bishop, ANn and Birkett, Betty. Drug-resistance in Plasmodium gallinaceum, and the persistence of paludrine-resistance after mosquito transmission

Feldman-Muehsam, B. On larvae and nymphs of some species of Palestinian Hyalomma. (With 12 Figures in the Text)

ShaRIF, M. The water relations of the larva of Xenopsylla cheopis (Siphonaptera) 148 


\section{Nos. 3, 4 (February 1949)}

Fastren, L. B. The effect of physical agents on hydatid scolex viability. (With 6 Figures in the Text)

Weiser, Jaroslav. Studies on some parasites of fishes. (With 2 Figures in the Text) .

157

Mrne, A. The ecology of the sheep tick, Ixodes ricinus L. Host relationships of the tick. Part 1. Review of previous work in Britain.

MrNe, A. The ecology of the sheep tick, Ixodes ricinus L. Host relationships of the tick. Part 2. Observations on hill and moorland grazings in northern England . . .

WIIson, S. G. Trypanosoma uniforme-Trypanosoma vivax infections in bovines and Trypanosoma uniforme infections in goats and sheep at Entebbe, Uganda. (With 22 Figures in the Text)

Ginavamuthu, C. P. A new copepod parasite, Lernanthropus dussumieria n.sp., from the gills of a Madras fish. (With 6 Figures in the Text) . . . . . . . .

van Cleave, Harley J. Pseudoporrorchis teliger, a new species of acanthocephala from Java. (With 5 Figures in the Text).

Dodgherty, Ellsworth C. A list of the trichostrongylid lungworms (Phylum Nematoda) and a key to the six genera. (With 2 Figures in the Text)

Dougherty, Ellsworth C. The phylogeny of the nematode family Metastrongylidae Leiper, [1909]: a correlation of host and symbiote evolution. (With 27 Figures in the Text) .

ARthor, D. R. The scutum of the tick, Ixodes ricinus L. (With 9 Figures in the Text) .

Matthews, R. E. F. Reactions of Cyphomandra betacea to strains of potato virus $X$. .

Rogers, W. P. and Lazards, Marian. The uptake of radioactive phosphorus from host tissues and fluids by nematode parasites. (With 5 Figures in the Text) .

Gerichter, Ch. B. Studies on the nematodes parasitic in the lungs of Felidae in Palestine. (With 27 Figures in the Text)

KrRK, R. The differentiation and nomenclature of Leishmania

Crofton, H. D. The ecology of immature phases of trichostrongyle nematodes. III. Larval populations on hill pastures. (With 3 Figures in the Text)

TRIM, A. R. The kinetics of the penetration of some representative anthelmintics and related compounds into Ascaris lumbricoides var. suis. (With 9 Figures in the Text)

Ganapati, P. N. and Tate, P. On the gregarine Lankesteria culicis (Ross), 1898, from the mosquito Aëdes (Finlaya) geniculatus (Olivier). (With 5 Figures in the Text)

LewIs, D. J. The distribution of Cimicidae (Hemiptera) in the Anglo-Egyptian Sudan. (With 4 Figures in the Text)

Chance, M. R. A. and Dirnhuber, P. The water-soluble vitamins of parasitic worms . .

Rogers, W. P. and Lazarus, Marian. Glycolysis and related phosphorus metabolism in parasitic nematodes. (With 6 Figures in the Text)

Jobling, B. Host-parasite relationship between the American Streblidae and the bats, with a new key to the American genera and a record of the Streblidae from Trinidad, British West Indies (Diptera). (With 3 Figures in the Text)

MaRkham, Roy and Smith, KenNerr M. Studies on the virus of turnip yellow mosaic. (With Plates IV-VII and 4 Figures in the Text) 